\title{
Toxoplasma gondii antibodies on domiciled cats from Lages municipality, Santa Catarina State, Brazil
}

\author{
Anticorpos contra Toxoplasma gondii em gatos domiciliados no município de Lages, Santa Catarina, Brasil \\ Luciana Dalla Rosa ${ }^{1 *}$; Anderson Barbosa de Moura ${ }^{1}$; Natascha Trevisani ${ }^{1}$; Alessandra Pereira Medeiros ${ }^{1}$; \\ Amélia Aparecida Sartor ${ }^{1}$; Antonio Pereira de Souza ${ }^{1}$; Valdomiro Bellato ${ }^{1}$ \\ ${ }^{1}$ Centro de Ciências Agroveterinárias, Universidade do Estado de Santa Catarina - UDESC
}

Received June 17, 2010

Accepted August 13, 2010

\begin{abstract}
Sera were collected from 300 domiciled cats from the municipality of Lages, Southern Brazil, to determine the prevalence of Toxoplasma gondii antibodies and risk factors associated. Tests for T. gondii antibodies were performed using indirect immunofluorescent antibody test (IFAT). Positive reactions with titers $\geq 1: 64$ were found in $43(14.33 \%)$ cats. A significant number of seropositive cats were $\geq 6$ month old $(\mathrm{p}=0.03758)$ and had access to the streets or/and rural areas $(\mathrm{p}=0.04185)$. The results indicate that T. gondii is widespread in cats in Lages with a prevalence of $14.33 \%$.
\end{abstract}

Keywords: Toxoplasma gondii, cats, IFAT, seroprevalence.

\section{Resumo}

Amostras de sangue foram obtidas de 300 gatos domiciliados para determinar a prevalência de anticorpos contra Toxoplasma gondii e possíveis fatores de risco. A detecção de anticorpos da classe IgG foi realizada por meio da Reação de Imunofluorescência Indireta (RIFI). Reaçóes positivas com títulos $\geq 1: 64$ foram encontradas em 43 (14,33\%) gatos. Os títulos encontrados variaram de 1:64 a 1:4096, sendo que 19 animais $(44,19 \%)$ tiveram titulação de 1:64, 18 animais $(41,86 \%)$ com 1:256, cinco animais $(11,63 \%)$ com 1:1024 e um animal $(2,32 \%)$ teve titulação de 1:4096. Foi verificada correlaçáo entre soropositividade dos felinos ao T. gondii e idade $(\mathrm{p}=0,03758)$ e com o acesso à rua e/ou zona rural $(\mathrm{p}=0,04185)$. Os resultados indicam que T. gondii está disseminado entre os gatos domiciliados de Lages, Estado de Santa Catarina, Brasil, com uma prevalência de 14,33\%.

Palavras-chave: Toxoplasma gondii, gatos, RIFI, soroprevalência.

Toxoplasmosis is a parasitic zoonosis caused by Toxoplasma gondii (NICOLLE; MANCEAUX, 1909), an intracellular coccidian protozoan parasite that infects all hot blood animals as intermediate hosts and members of the Felidae Family (domestic and wild) as definitive hosts.

The objective of the present study was to determine the seroprevalence of $T$. gondii IgG antibodies in domestic cats from the city of Lages, State of Santa Catarina, Southern Brazil, by using indirect immunofluorescence antibody test (IFAT) and to assess its correlation with the study variables.

Blood samples were collected from 300 domiciled cats from August 2008 to July 2009. These samples were stored in sterile tubes containing one drop of anticoagulant (EDTA 10\%), labeled and kept in isothermal boxes on ice and transported to the Laboratório de Parasitologia e Doenças Parasitárias do Centro de Ciências Agroveterinárias (CAV) of Universidade do Estado de Santa Catarina (UDESC).

\footnotetext{
*Corresponding author: Luciana Dalla Rosa

Centro de Ciências Agroveterinárias, Universidade do Estado de Santa Catarina - UDESC, Av. Luiz de Camóes, 2090, Conta Dinheiro, CEP 88520-000 Lages - SC, Brazil; e-mail: ludallarosa@hotmail.com
}

Sera collected were analyzed through IFAT, according to the method described by Camargo (1964). Positive and negative control sera were included on each slide. The samples were tested at two-fold serial dilutions starting at 1:64.

Epidemiological information were obtained through questionnaires applied to the owners including questions about age, sex, breed, diet, predators, shelter (house or flat), street or rural access and contact with other animal species.

The relationship between the study variables and seropositivity to $T$. gondii was determined through the chi-square test $\left(\chi^{2}\right)$ and Fisher's exact test $(\mathrm{p}<0.05)$.

Of 300 sera samples analyzed, 43 (14.33\%) were positive for T. gondii (IFAT $\geq 64$ ) with titers ranging from 1:64 to 1:4096. Nineteen (44.19\%) cats had a titer of 1:64, 18 animals (41.86\%) of 1:256, five (11.63\%) of 1:1024 and one animal (2.32\%) had a titer of 1:4096.

The rate of seropositive cats in the city of Lages was lower than 37.96\% reported by Pinto et al. (2009) in a study of resident cats in the city of Porto Alegre, Rio Grande do Sul State, and also than 25\% found in the city of Araçatuba, São Paulo State (BRESCIANI et al., 2006). Similar results were reported by 
Langoni et al. (2001) in three cities in Sáo Paulo (São Paulo, Botucatu and Bauru) and one city in Paraná (Foz do Iguaçu) who found $19.4 \%$ seropositivity in 191 sera from cats analyzed and Gonçalves Netto et al. (2003) in Niterói, Rio de Janeiro State, who found a seropositivity of $19.5 \%$ in 41 sera from cats.

The serologically positive reaction to T. gondii was correlated with the cat's age $(\mathrm{p}=0.03758)$ and access to the streets or rural areas $(\mathrm{p}=0.04185)$.

As for age, of those positive cats, $97.67 \%$ (42/43) were older than six months. Pena et al. (2006) found similar positive results in adult (41.4\%) and young cats (13.7\%). The relationship between prevalence of infection and age can be explained by the fact that older animals are more likely to have been previously exposed to the parasite.

The animals that had access to the streets accounted for $73.67 \%(221 / 300)$ of all cats examined, and of these, $14.93 \%$ (33/221) were reactive to $T$. gondii, showing higher prevalence than those living with their owners, $4.44 \%$ (2/45). Among positive animals, $76.74 \%(33 / 43)$ had access to the streets. Similar results were described by Vargas (2006) in Curitiba, Paraná State, who found $16.4 \%$ seropositivity among cats with access to the streets.

In the present study, animals with access to rural areas accounted for $11.33 \%$ (34/300) of all cats examined, and of these, $23.53 \%$ $(8 / 34)$ were positive. This rate is lower than that was reported by Cavalcante et al. (2006) in the city of Monte Negro, Rondônia State, who found $87.3 \%$ of positive cats from rural areas.

The prevalence of infection was not significantly different regarding sex, breed, diet, predators, shelter and contact with other animal species. Garcia et al. (1999) also did not find a significantly different prevalence of infection by sex. Langoni et al. (2001) did not find a significantly different prevalence of $T$. gondii by sex, breed, origin or age.

Maintaining cats within households, avoiding feeding them with raw meat, and controlling intermediate hosts can all contribute to reduce the prevalence of toxoplasmosis in cats (ELBEZ-RUBINSTEIN et al., 2009).

The study results showed the presence of $T$. gondii infection in $14.33 \%$ of the resident cats in the city of Lages, Brazil.

\section{References}

BRESCIANI, K. D. S. et al. Antibodies to Neospora caninum and Toxoplasma gondii in domestic cats from Brazil. Parasitology Research, v. 100, n. 2, p. 281-285, 2006.

CAMARGO, M. E. Improved technique of indirect immunofluorescence for serological diagnosis of toxoplasmosis. Revista do Instituto de Medicina Tropical, São Paulo, v. 6, n. 3, p. 117-118, 1964.

CAVALCANTE, G. T. et al. Seroprevalence of Toxoplasma gondii antibodies in cats and pigs from rural Western Amazon, Brazil. Journal of Parasitology, v. 92, n. 4, p. 863-864, 2006.

ELBEZ-RUBINSTEIN, A. et al. Congenital toxoplasmosis and reinfection during pregnancy: case report, strain characterization, experimental model of reinfection, and review. The Journal of Infectious Diseases, v. 199, n. 2, p. 280-285, 2009.

GARCIA, J. L. et al. Soroepidemiologia da toxoplasmose em gatos e cães de propriedades rurais do município de Jaguapitã, estado do Paraná, Brasil. Ciência Rural, v. 29, n. 1, p. 99-104, 1999.

GONÇALVES NETTO, E. et al. Ocorrência de gatos soropositivos para Toxoplasma gondii Nicolle e Manceaux, 1909 (Apicomplexa: Toxoplasmatinae) na cidade de Niterói, Rio de Janeiro. Revista Brasileira de Parasitologia Veterinária, v. 12, n. 4, p. 145-149, 2003.

LANGONI, H. et al. Prevalência de toxoplasmose em gatos dos Estados de São Paulo e Paraná. Brazilian Journal of Veterinary Research and Animal Science, v. 38, n. 5, p. 243-244, 2001.

NICOLLE, C.; MANCEAUX, L. Sur un protozoaire nouveau du gondii. Les Comptes Rendus de l'Académie des Sciences, v. 147, p. 763-766, 1909.

PENA, H. F. J. et al. Toxoplasma gondii infection in cats from São Paulo state, Brazil: Seroprevalence, oocyst shedding, isolation in mice, and biologic and molecular characterization. Research in Veterinary Science, v. 81, n. 1 , p. 58-67, 2006.

PINTO, L. D. et al. Soroepidemiologia de Toxoplasma gondii em gatos domiciliados atendidos em clínicas particulares de Porto Alegre, RS, Brasil. Ciência Rural, v. 39, n. 8, p. 2464-2469, 2009.

VARGAS, C. S. G. Títulos de anticorpo da classe IgG anti Toxoplasma gondii (Nicolle \& Manceaux, 1908) e de oocistos em fezes de gatos de rua (Felis catus - Linnaeus, 1758) em Curitiba, Paraná. 2006. 66 f. Dissertação (Mestrado em Ciências Veterinárias)-Setor de Ciências Agrárias, UFPR, Curitiba, 2006. 